\title{
Fungal dermatitis by Scopulariopsis brevicaulis in Guinea pig (Cavia porcellus)
}

\author{
Dermatite fúngica por Scopulariopsis brevicaulis \\ em Porquinho da Índia (Cavia porcellus)
}

\author{
Guilherme Augusto Marietto Gonçalves ${ }^{1^{*}}$ (D), Alexandre Alberto Tonin² (B)
}

\begin{abstract}
Fungal dermatitis is classified into superficial, cutaneous and subcutaneous mycoses. However, the incidence of fungal dermatitis in small mammals is relatively low. Among rodents guinea pig the most affected specie, however it usually has an asymptomatic pattern. The present text reports an unusual case of fungal dermatitis in Cavia porcellus caused by Scopulariopsis brevicaulis. The animal was received with complaint of alteration of coat around the neck, as well as report of incorrect feeding management. During the physical examination the presence of a dry and crusty dermatitis, negative on fluorescence test of wood. Samples of blood, skin, scabs and hair were collected for parasitic and mycological analysis. The hematological evaluation showed only a discrete eosinophilia; no ectoparasites were observed, but it was noticed the presence of Scopulariopsis brevicaulis. The animal underwent terbinafine and griseofulvin protocol, with total regression of the lesions after 30 days. S. brevicaulis is an unusual geophilic fungus causing animal mycosis, presenting more pathological reports in human mycoses, thus, representing a zoonotic potential. According to the clinical findings and results obtained from mycology assay, it was diagnosed dermatitis by Scopulariopsis brevicaulis, secondary to nutritional deficiency. The combined use of topical terbinafine with systemic griseofulvin was efficient in the treatment. Finally, it was recommended a dietary correction.
\end{abstract}

KEYWORDS: Rodentia; Exotic pets; Dermatology; Micology; Public Health.

\begin{abstract}
RESUMO: As dermatites fúngicas são classificadas em micoses superficiais, micoses cutâneas e micoses subcutâneas. No entanto, a ocorrência de dermatites fúngicas em pequenos mamíferos é incomum, sendo que entre os roedores o porquinho da Índia é a espécie mais acometida e a infecção costuma ser assintomática. O presente artigo relata um caso incomum de dermatite fúngica em Cavia porcellus causado pelo fungo Scopulariopsis brevicaulis. $\mathrm{O}$ animal foi atendido devido à queixa de alteração de pelagem ao redor do pescoço e erros no manejo alimentar. Durante o exame físico observou-se a presença de uma dermatite crostosa de aparência seca, negativa no teste de fluorescência sob lâmpada de Wood para detectar dermatófitos. Foi coletado sangue e também amostras de pele, crostas e pelos para análise parasitária e cultivo micológico. Na avaliação hematológica observou-se apenas uma eosinofilia discreta, no parasitológico não foram observados ectoparasitas. No cultivo micológico foi isolado Scopulariopsis brevicaulis. O animal foi tratado com terbinafina e griseofulvina havendo regressão total das lesões após 30 dias de terapia antifúngica. S. brevicaulis é um fungo geofílico incomum em casos de micose em animais, sendo mais relatado em micoses humanas e havendo um potencial zoonótico. Assim, baseado nos achados clínicos e exames laboratoriais concluiu-se que o caso se tratava de uma dermatite fúngica causada por Scopulariopsis brevicaulis secundária a deficiência nutricional, sendo que o uso combinado de terbinafina tópica com a griseofulvina sistêmica foi eficiente no tratamento em combinação com a correção da dieta alimentar.
\end{abstract}

PALAVRAS-CHAVE: Rodentia; Animais exóticos; Dermatologia; Micologia; Saúde pública.

\section{INTRODUCTION}

Fungal dermatitis is classified into superficial mycoses, which are restricted to the stratum corneum or on the animal fur without dermal reaction; cutaneous mycoses, involving all keratinized structures and epidermis; and subcutaneous mycoses, usually of traumatic origin and affecting cutaneous and subcutaneous tissues (HARGIS; GINN, 2012). Among the cutaneous mycoses in animals the most common are the dermatophytosis, caused by fungi of the genus Microsporum, Trichophyton and Epidermophyton, the last 
one more frequently affecting humans (CHENGAPPA; POHLMAN, 2013).

The incidence of fungal dermatitis in small mammals is relatively low, and specifically Rodentia Class, Cavia porcellus is the most affected specie (POLLOCK, 2003). Clinical signs of fungal dermatitis in $C$. porcellus usually include alopecia, scaling and crusting skin, with the head as the most affected region of the body (KRAEMER et al., 2013). Usually animals do not present, or have minimal pruritus (DONNELLY et al., 2000).

Therefore, we are reporting an unusual case of fungal dermatitis in C. porcellus by Scopulariopsis brevicaulis.

\section{CASE REPORT}

A male $C$. porcellus, Five months old, weighing $480 \mathrm{~g}$, was sent to the Hospital Veterinário das Faculdades Integradas de Ourinhos - FIO, (Ourinhos, SP, Brazil) for veterinary evaluation. It was reported a history of change in the patter of the coat around the neck. It was fed with a ration based in the mixture of seeds with rabbit ration (unidentified manufacturers) and apple, being kept in galvanized cage and with access to open garden, having as contact animal a dog.

A physical examination was carried out and an easy fragmentation of the hairs around the neck was observed, as well as opacity of the hair uncoated spots. The animal was submitted to a transillumination (Wood lamp); however no fluorescence activity was observed (Figure 1A). After this procedure, the patient was sedated $(5 \mathrm{mg} / \mathrm{kg}$ de ketamine associated with $0.5 \mathrm{mg} / \mathrm{kg}$ of midazolan, intramuscularly) as recommended by Mayer (2013). Then, it was observed clearly the presence of dry-appearing crustal dermatitis (Figure 1B) and a deep skin scraping was performed in order to observe possible ectoparasites, as well as to provide samples for mycological culture. Additionally, blood sample was collected, by jugular vein puncture, for hematological analysis.

In the microscopic examination, aiming observation of ectoparasites, the skin and hair samples were prepared on a glass slide with a drop of $10 \%$ potassium solution, analyzed under optical microscope. However, no parasite structures were observed in these samples. The hematological analysis

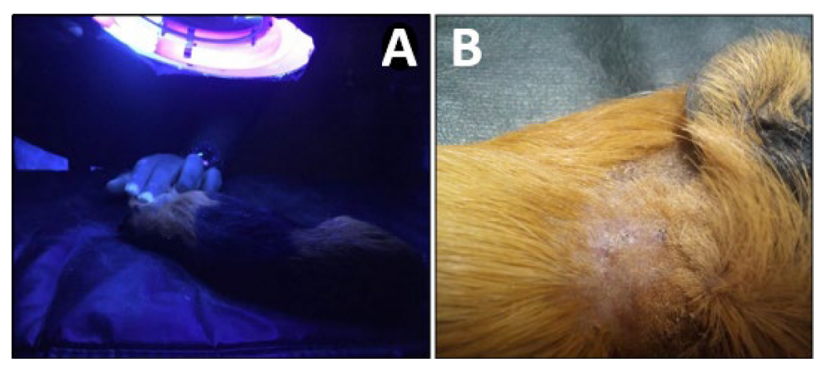

Figure 1. A) Transillumination exam (Wood lamp) in Cavia porcellus. Exam showed negative result testing tryptophanproducing fungi. B) Dry-appearing crustal dermatitis in the neck region of Cavia porcellus. Skin lesion was only visible after tricotomy. showed only a slight eosinophilia (Table 1), while all the other parameters were within normal limits.

For mycological examination the skin and hairs sample were incubated in Sabouraud-Dextrose Agar and Dermatophyte Test Medium (DTM), at $25^{\circ} \mathrm{C}$ for two weeks. There was no growth in DTM agar (it was kept under incubation for up to four weeks), however, it was observed growth of colonies. From these colonies we carried out imprint on a slide, followed by morphological identification as describer by Markey et al. (2013) and Sandoval-Dennis et al. (2016), using cotton dye (lactophenol). The colonies macroscopically observed were white (slightly yellowish) and glabrous in appearance, and microscopically, the fungus had short conidiophores with large, cylindrical thick-walled cell conidia. According to the characteristics found, it was observed that the isolated sample was compatible with Scopulariopsis brevicaulis.

Once confirmed it, the animal underwent to a protocol of $1 \%$ terbinafine (topical) and griseofulvin at $100 \mathrm{mg} / \mathrm{kg}$, orally, every 24 hours, for 30 consecutive days, as suggested by Mayer (2013). After this period there was an excellent regression of the lesions, allowing a fully coat covering on the affected area. In parallel, there was also a diet reformulation,

Table 1. Hematological analysis of the Cavia porcellus.

\begin{tabular}{|c|c|c|}
\hline Parameters analyzed & Case & $\begin{array}{l}\text { Reference } \\
\text { values* }\end{array}$ \\
\hline \multicolumn{3}{|l|}{ Hematologic values } \\
\hline Hematocrit & 45 & $39-55$ \\
\hline Hemoglobin (g/dL) & 13.5 & $11.6-16.9$ \\
\hline Red blood cells $\left(x 10^{6} / \mu \mathrm{L}\right)$ & 5.2 & $4.5-6.4$ \\
\hline Mean corpuscular volume (fL) & 85 & $80-89$ \\
\hline $\begin{array}{l}\text { Mean corpuscular hemoglobin } \\
\text { contration }(\mathrm{g} / \mathrm{dL})\end{array}$ & 31 & $29-32$ \\
\hline White blood cells $\left(x 10^{3} / \mu \mathrm{L}\right)$ & 10.7 & $2.9-14.4$ \\
\hline Lymphocytes (\%) & 57 & $28-84$ \\
\hline Neutrophils (\%) & 22 & $12-62$ \\
\hline Monocites (\%) & 5 & $0-9$ \\
\hline Eosinophils (\%) & 15 & $0-14$ \\
\hline Basophils (\%) & 1 & $0-2$ \\
\hline \multicolumn{3}{|l|}{ Biochemical values } \\
\hline Alanine aminotransferase (U/L) & 15 & $0-61$ \\
\hline Aspartate aminotransferase (U/L) & 40 & $0-90$ \\
\hline Albumin (g/dL) & 3.1 & $2.6-4.1$ \\
\hline Alkaline phosphatase (U/L) & 112 & $0-418$ \\
\hline Blood urea nitrogen (mg/dL) & 12.8 & $9.4-28.9$ \\
\hline Creatinine (mg/dL) & 0.2 & $0-0.87$ \\
\hline Protein, total (g/dL) & 5.1 & $4.4-6.6$ \\
\hline Glucose (mg/dL) & 139 & $89-287$ \\
\hline
\end{tabular}

*Quesenberry et al. (2012). 
recommending the replacement of seed mix by extruded ration specific for $C$. porcellus, supplementation with of ascorbic acid and alfalfa (Medicago sativa), fresh or in the form of hay.

\section{DISCUSSION}

Scopulariopsis brevicaulis is a geophilic fungus with reports of occasional infection in horses, dogs and humans (VANGEEL et al., 2000; WU et al., 2009; PETANOVIC et al., 2010). The infection by $S$. brevicaulis it was already reported in $C$. porcellus, however related to stress factors (COUTINHO et al., 2001). In our report, we believe that the predisposing factor for the infection was the nutritional imbalance, which probably affected the immunity of the animal.

The species commonly involved in cases of dermatomycosis in C. porcellus are T. mentogrophytes, Microsporum gypseum and $M$. canis (DONNELLY et al., 2000; RICHARDSON, 2000; PIGNON; MAYER, 2020). Despite being susceptible to infection by $S$. brevicaulis, $C$. porcellus is usually an asymptomatic carrier, being a species considered as a source of infection of these zoonotic dermatophytes for man, especially children (VANGEEL et al., 2000; KRAEMER et al., 2013). However, studies indicate that the degree of contamination of these animals by these fungi is relatively low.

In a study developed by Vangeel et al., (2000), the contamination by dermatophytes represented $3.5 \%$, being found, among other fungi, positivity to $S$. brevicaulis in $15 \%$ of animals. Kraemer et al. (2012) and Thomson et al. (2015) reported the prevalence of dermatophytes in $38.1 \%$ and $7.7 \%$, respectively, with no detection of $S$. brevicaulis. In another study, d'Ovidio et al. (2014a) observed a prevalence of Scopulariopsis spp. in $3.4 \%$ evaluated animals, do not reporting other dermatophytes more common to the species.

A study evaluating the sensitivity to antifungal samples on S. brevicaulis samples (CUENCA-ESTRELLA et al. 2003) demonstrated the inefficiency of flucytosine and itraconazole, in inhibition of fungus, however, reporting good activity when amphotericin B, voriconazole and terbinafine were used. Thus, the association of terbinafine with griseofulvin was chosen, demonstrating healing on the lesions.

For differential diagnosis, in cases of dermatitis in $C$. porcellus, besides exams for other fungi, it is recommended also to consider the possibility of infestation by ectoparasites such as Chirodiscoides caviae (Acarina: Sarcoptiformes), which is a specific species of Guinea Pig; however, the mite usually causes an itchy dermatitis in cases of high infestation (D'OVIDIO; SANTORO, 2014) while fungal dermatitis tend to be non-itchy (DONNELLY et al., 2000). The skin scraping examination, for direct observation of the parasite, in recommended to identify or rule out scabies dermatitis, as performed in this study.

The use of Wood lamp is can be used as a screening technique, however, it does not rule out the chances of fungal dermatitis when negative, since only tryptophanproducing fungi, such as some species of Tricophyton, Malassezia and Microsporum present the phenomenon of fluorescence by UV radiation (DUBUGRAS et al., 1992). Therefore, whenever there is suspicion of cutaneous mycosis, it should be used for discarding or confirmation of tryptophan-producing fungi.

Despite the risk of zoonotic transmission (COUTINHO et al., 2001; PETANOVIC et al., 2010), there was no report of contamination by the owners or other contact animals.

According to the clinical findings and the examinations carried out we conclude that the manifestations was due a fungal dermatitis caused by Scopulariopsis brevicaulis, secondary to nutritional deficiency, and the use of topical terbinafine in combination with systemic griseofulvin was efficient in the treatment, when in combination with a dietary correction.

\section{REFERENCES}

CHENGAPPA, M. M.; POHLMAN, L. M. Dermatophytes. In: MCVEY, D. S.; KENNEDY, M.; CHENCAPPA, M. M. Veterinary Microbiology. 3. ed. Ames: Wiley-Blackwell, 2012. p. 321-325.

COUTINHO, S. D. A.; CARVALHO, V. M.; COSTA, E. O. Surto de dermatomicose em cobaias por Trichophyton mentogrophytes e Scopulariopsis brevicaulis. ClínicaVeterinária, v. 6, n. 31, p. 30-32, 2001.

CUENCA-ESTRELLA, M.; GOMEZ-LOPEZ, A.; MELLADO, E.; BUITRAGO, M. J.; MONZÓN, A.; RODRIGUEZ-TUDELA J. L. Scopulariopsis brevicaulis, a fungal pathogen resistant to broad-spectrum antifungal agents. Antimicrobial Agents and Chemotherapy, v. 47, n. 7, p. 2339-2341, 2003.

DONNELLY, T. M.; RUSH, E. M. LACKNER, P. A. Ringworm in small exotic pets. Seminars in Avian and Exotic Pet Medicine, v. 9, п. 2, p. 82-93, 2000.
D'OVIDIO, D.; GRABLE, S. L.; FERRARA, M.; SANTORO, D. Prevalence of dermatophytes and other superficial fungal organisms in asymptomatic guinea pigs in Southern Italy. Journal of Small Animal Practice, v. 55, n. 7, p. 355-358, 2014.

D'OVIDIO, D.; SANTORO, D. Prevalence of fur mites (Chirodiscoides caviae) in pet guinea pigs (Cavia porcellus) in southern Italy. Veterinary Dermatology, v. 25, n. 2, p. 125-e38, 2014.

DUBUGRAS, M. T.B.; LARSSON, C. E.; LEDON, A. L. B. P.; GAMBALE, $W$. Dermatofitoses e leveduroses de cães e gatos - Aspectos diagnósticos. Brazilian Journal of Veterinary Research and Animal Science, v. 29, п. 2, p. 273-87, 1992.

HARGIS, A. M.; GINN, P. E. The integument. In: ZACHARY, J. F; MCGAVIN, M. D. Pathology Basis of Veterinary Diseases. 5. ed. St. Louis: Elsevier, 2012. p. 972-1084. 
PIGNON, C.; MAYER, J. Guinea pigs. In: QUESENBERRY, K. E.; ORCUTT, C. J.; MANS, C.; CARPENTER, J. W. Ferrets, Habbits and Rodents: Clinical, Medicine and Surgery. 4. ed. St. Louis: Elsevier Saunders, 2020. p. 270-297.

KRAEMER, A.; MUELLER, R. S.; WERCKENTHIN, C.; STRAUBINGER, R. K.; HEIN, J. Dermatophytes in pet Guinea pigs and rabbits. Veterinary Microbiology, v. 157, n. 1-2, p. 208-213, 2012.

KRAEMER, A.; HEIN, J.; HEUSINGER, A.; MUELLER, R. S.Clinical signs, therapy and zoonotic risk of pet guinea pigs with dermatophytosis. Mycoses, v. 56, n. 2, p. 168-172, 2013.

MAYER, J. Rodents. In: CARPENTER, J. W.; MARION, C. J. Exotic Animal Formulary. 4. ed. St. Louis: Elsevier Saunders, 2013. p. 477-516.

MARKEY, B.; LEONARD, F.; ARCHAMBAULT, M.; CULLINANE, A.; MAGUIRE, D. Clinical Veterinary Microbiology. 2. ed. New York: Mosby Elsevier, 2013.

PETANOVIĆ, M.; TOMIĆ PARADZIK, M.; KRISTOF, Z.; CVITKOVIĆ, A.; TOPOLOVAC, Z. Scopulariopsis brevicaulis as the cause of dermatomycosis. Acta Dermatovenerologica Croatica, v. 18, n. 1, p. 8-13, 2010.
QUESENBERRY, K. E.; DONNELLY, T. M.; MANS, C. Biology, husbandry, and clinical techniques of Guinea pigs and Chinchilas. In: QUESENBERRY, K. E.; CARPENTER, J. W. Ferrets, Rabbits and Rodents. 3. ed. St. Louis: Elsevier Saunders, 2012. p. 279-294.

SANDOVAL-DENIS, M; GENÉ, J.; SUTTON, D. A.; CANO-LIRA, J. F.; HOOG, G. S.; DECOCK, C. A.; WIEDERHOLD, N. P.; GUARRO, J. Redefining Microascus, Scopulariopsis and allied genera. Persoonia, v. 36, p. 1-36, 2016.

RICHARDSON, V. C. G. Diseases of Domestic Guinea Pigs. 2. ed. Ames: Blackwell Science, 2000.

THOMSON, P.; MONSALVES, P.; MAIER, L.; SILVA, V. Colonización por dermatofitos en cuyes (Cavia porcellus) mantenidos en tiendas de mascotas. Primer reporte en Santiago de Chile. Revista Iberoamericana de Micología, v. 32, n. 2, p. 103-105, 2015.

VANGEEL, I.; PASMANS, F.; VANROBAEYS, M.; DE HERDT, P.; HAESEBROUK, F. Prevalence of dermatophytes in asymptomatic guinea pig and rabbits. Veterinary Record, v. 146, n. 15, p. 440-441, 2000.

WU, C. Y.; LEE, C. H.; LIN, H. L.; WU, C. S. Cutaneous granulomatous infection caused by Scopulariopsis brevicaulis. Acta DermatoVenerologica, v. 89, n. 1, p. 103-104, 2009. 